\title{
Mutual Information Analyses of Neuron Selection Techniques in Synchronous Exponential Chaotic Tabu Search for Quadratic Assignment Problems
}

\author{
Tetsuo Kawamura Non-member (Tokyo Denki University, 09kme17@ms.dendai.ac.jp) \\ Yoshihiko HorioＮon-member (Tokyo Denki University, horio@eee.dendai.ac.jp) \\ Mikio Hasegawa Non-member (Tokyo University of Science, hasegawa@ee.kagu.tus.ac.jp)
}

Keywords: mutual information, high-dimensional chaotic dynamics, chaotic neural network, QAP, tabu search

The tabu search was implemented on a neural network with chaotic neuro-dynamics. This chaotic exponential tabu search shows great performance in solving quadratic assignment problems (QAPs). To exploit inherent parallel processing abilities of analog hardware systems, a synchronous updating scheme, was proposed. However, several neurons may fire simultaneously with the synchronous updating. As a result, we cannot determine only one candidate for the 2opt exchange from the many fired neurons. To solve this problem, several neuron selection methods, which select one specific neuron among the fired neurons, were proposed.

In this paper, we analyze the dynamics of the chaotic neural network with the neuron selection methods by means of the spatial and temporal mutual information. The dynamics of the chaotic neural network are high-dimensional and suffer from large external effects from the neuron selection methods and 2-opt exchanges. Therefore, evaluation methods for low-dimensional chaotic dynamical systems such as Lyapunov analysis and dimensional analysis are difficult to be applied. In addition, we assume an analog/digital hybrid hardware system. Therefore, analysis methods, which require high-precision and multi-channel measurements, are not suitable. In contrast, the mutual information uses binary variables only. Therefore, the mutual information is suitable for evaluation of the high-dimensional dynamics observed from hardware systems.

Dynamics from 3 neuron selection methods (Method A, B, and $\mathrm{C}$ ) are evaluated through spatial and temporal mutual information. The average spatial mutual information $M I_{s p}$ is given as

$$
\begin{aligned}
M I_{s p} & =\frac{1}{N^{2}} \sum_{i=1}^{N} \sum_{j=1}^{N} M I_{i j}, \cdots \ldots \ldots \ldots \ldots \\
M I_{i j} & =H\left(x_{i}\left(t_{n}\right)\right)-H\left(x_{i}\left(t_{n}\right) \backslash x_{j}\left(t_{n-1}\right)\right),
\end{aligned}
$$

where $N$ is the number of neurons, $M I_{i j}$ is the spatial mutual information of the $i$ th neuron obtained from the $j$ th neuron, $H\left(x_{i}\left(t_{n}\right)\right)$ is entropy at time $t_{n}$, and $H\left(x_{i}\left(t_{n}\right) \backslash x_{j}\left(t_{n-1}\right)\right)$ is conditional entropy. The average temporal mutual information $M I_{t m p}$ is given as

$$
\begin{aligned}
& M I_{t m p}=\frac{1}{N} \sum_{i=1}^{N} M I_{i}, \ldots \ldots \ldots \ldots \ldots . \\
& M I_{i}=H\left(x_{i}\left(t_{n}\right)\right)-H\left(x_{i}\left(t_{n}\right) \backslash x_{i}\left(t_{n-1}\right)\right),
\end{aligned}
$$

where $M I_{i}$ is the temporal mutual information of the $i$ th neuron.

Figure 1 shows the relationship between $M I_{s p}$ and the average gap from the optimum solution for Method A to C when we solve Nug 30 problem. In addition, results for the ordinary exponential chaotic tabu search are plotted as $\mathrm{U}=1$ in Fig. 1. From the figure, $M I_{s p}$ of the Method B and C show low values. On the other hands, those of the Method A are distributed to higher values when the average gaps from the optimum solution are large. Since the solving performances of the Method B and C are superior to that of the Method A, $M I_{s p}$ should be low. From further analyses, we also show that $M I_{t m p}$ should take particular values, which depend on the instances, for good solving performance.

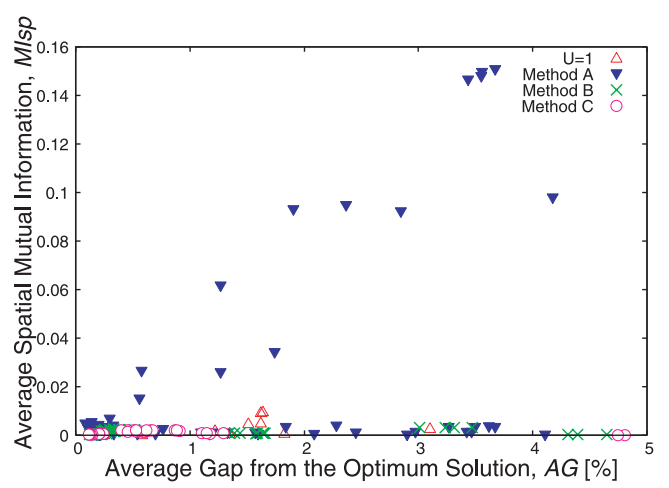

Fig. 1. Average spatial mutual information $M I_{s p}$ vs. average gap from the optimum solution for Nug30. 


\title{
二次割当問題のための同期更新指数減衰カオスタブーサーチの ニューロン選択法の相互情報量による解析
}

\author{
非会員 河村 鉄夫* 非会員 堀尾 喜彦* \\ 非会員 長谷川幹雄**
}

\author{
Mutual Information Analyses of Neuron Selection Techniques in Synchronous \\ Exponential Chaotic Tabu Search for Quadratic Assignment Problems
}

Tetsuo Kawamura*, Non-member, Yoshihiko Horio*, Non-member, Mikio Hasegawa**, Non-member

\begin{abstract}
The tabu search was implemented on a neural network with chaotic neuro-dynamics. This chaotic exponential tabu search shows great performance in solving quadratic assignment problems (QAPs). To exploit inherent parallel processing abilities of analog hardware systems, a synchronous updating scheme, where all the neurons in the network are updated at the same time, was proposed. However, several neurons may fire simultaneously with the synchronous updating. As a result, we cannot determine only one candidate for the 2-opt exchange from the many fired neurons. To solve this problem, several neuron selection methods, which select one specific neuron among the fired neurons, were proposed. These neuron selection methods improved the performance of the synchronous updating scheme. In this paper, we analyze the dynamics of the chaotic neural network with the neuron selection methods by means of the spatial and temporal mutual information. Through the analyses, the network solution search dynamics of the exponential chaotic tabu search with different neuron selection methods are evaluated.
\end{abstract}

キーワード : 相互情報量, 高次元カオスダイナミクス, カオスニューラルネットワーク, 二次割当問題, タブーサーチ

Keywords: mutual information, high-dimensional chaotic dynamics, chaotic neural network, QAP, tabu search

\section{1. はじめに}

タブーサーチ(1) をニューラルネットワークを用いて実現 する方法が提案されている ${ }^{(2) \sim(4)}$ 。この方法では, カオス ニューロンモデルの不応性により指数的に減衰する夕ブー サーチを実装し, カオスニューラルネットワークのカオス ダイナミクスで 2-opt 交換アルゴリズムを駆動する。この 時, カオスニューロンの発火によって 2-opt 交換の対象を 決定する。この指数減衰カオスタブーサーチは, 巡回セー ルスマン問題や二次割当問題 $(\mathrm{QAP})^{(5)}$ の解法において優 れた性能を示す (2) (4)。

我々は, 問題サイズ 10 の QAP を解く指数的減衰カオス

\footnotetext{
* 東京電機大学 大学院 工学研究科

T 101-8457 東京都千代田区神田錦町 2-2

Graduate School of Engineering, Tokyo Denki University,

2-2, Chiyoda-ku, Tokyo, 101-8457

** 東京理科大学 工学部 電気工学科

干 102-0073 東京都千代田区九段北 1-14-6

Department of Electrical Engineering, Tokyo University of Science

1-14-6, Kudankita, Chiyoda-ku, Tokyo, 102-0073
}

タブーサーチを, 実数の扱いが可能なアナログ集積回路を 核とした, 300 次元のアナログ/ディジタル混成ハードウェ アプロトタイプシステムとして実装した ${ }^{(6)}$ 。また, 実験に より, プロトタイプハードウェアシステムが優れた性能を 有していることを確認した。現在では, 10,000 個のカオス ニューロンを用いた 30,000 次元のシステムが実現可能で あり (7), 今後のハードウェアの小型化, 高次元化により, さらに大規模な組合せ最適化問題への応用が可能と考えら れる。

さらに，指数減衰カオスタブーサーチをハードウェアに より並列的に動作させるため, 全てのニューロンの状態を 同時に更新する同期更新方式を提案した ${ }^{(9)}(10)$ 。従来の非 同期更新方式のカオスタブーサーチでは，アナログ回路を 核としたハードウェアの利点である並列処理が困難であり, サイズの大きい QAP を解く場合, ニューロン一つ一つを逐 時的に状態更新するのに多くの時間を要する。これに対し, 同期更新方式では，複数のニューロンの並列処理により高 速化が可能になる上，実行時間が QAP の問題サイズに依 存しなくなる。しかし, 同期更新方式では, 複数個のニュー ロンが同時に発火する可能性がある。このため, 2-opt 交 
換の候補をニューロンの発火状態から一意に決定する事が できない。そこで，発火した複数個のニューロンの情報か ら 2-opt 交換を行う対象を一つに決定するためにニューロ

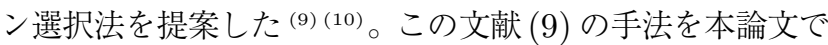
は「ニューロン選択法 $\mathrm{A} 」$ と呼ぶ。また, このニューロン 選択法 $\mathrm{A}$ の性能をさらに向上させるために，ハードウェア 化を念頭に置いた多数のニューロン選択法を考案し，それ らの性能を調査した。その結果, 最も解法能力が高かった ニューロン選択法を本論文中では「ニューロン選択法 B」と 呼ぶ。この手法については文献 (14) で報告した。さらに, ハードウェアを考慮に入れた実験により，これらのニュー ロン選択法の有効性を確認した ${ }^{(11)}$ 。しかしながら，ニュー ロン選択法 B は結果としてヒューリスティック解法として は直感に反した方策となっており，この方法の高い解法能 力にはシステムのダイナミクスが深く関わっていると考え られるものの, どのようなダイナミクスが解法能力に寄与 しているか未だ分かっていない。

ところで，本論文で扱う指数減衰カオスタブーサーチに は多数の調整パラメータが存在し, これらのパラメータ值 が取り得る範囲も広い。システムが高い解法能力を持つた めには，これらのパラメータ值を適当な值にチューニング する必要がある。従って，そのままハードウェア実装を行 うと, 広いパラメータレンジに対応した可変ハードウェア を作る必要があり，回路規模が大きくなる，パラメー夕の 設定精度が悪化するなどの不都合が生じる。もし，どのよ うなダイナミクスが有効であるかが分かれば，同等のダイ ナミクスを発生させるようにネットワークパラメータ值の 範囲を限定することが可能となる。これにより，回路パラ メータの可変範囲をあらかじめ絞り込むことが可能となる。 その結果，ハードウェアをより小型化・高速化でき，より 大規模な問題に適用する事が可能になると考えられる。

そこで本論文では，ニューロン選択法を用いた同期更新 指数減衰カオスタブーサーチの解探索ダイナミクスを, 相 互情報量解析により評価する。

相互情報量を用いる第 1 の理由は, 本研究で対象とする ハードウェアシステムは大規模で次元が非常に高く, 低次 元カオスシステムで用いられるリアプノフスペクトラムや フラクタル次元解析などの手法が適用できないが，相互情 報量は高次元カオスニューロダイナミクスによる時空間的 な情報の動きを定量化できるためである。さらに，ハード ウェアシステムから多チャネルのアナログ信号をカオスダ イナミクスの解析に必要と考えられる高い精度で観測する のは困難であり，離散值のみを用いる相互情報量が有効で あると考えられるためである。

相互情報量を用いた第 2 の理由は，相互情報量には同期 更新指数減衰カオスタブーサーチシステムの解探索ダイナ ミクスが反映されていると考えられるからである。本論文 で対象とするシステムでは，個々のニューロンの発火に基 づいて 2-opt 交換を行うことにより解を探索する。すなわ ち, ニューロン選択法中の時空間的な発火ダイナミクスと
解の探索ダイナミクスには密接な関係がある。本論文で用 いる空間相互情報量と時間相互情報量には時空間的な発火 情報が含まれているので，これらはシステムの解探索ダイ ナミクスの 1 つの尺度として適している。しかし，その一 方で，相互情報量は探索ダイナミクスの間接的な指標でし かない。

そこで, 解探索ダイナミクスが直感的に理解しやすい方 法で，ニューロン選択法 B とほぼ同等である「ニューロン 選択法 C」を比較対象として用いる。つまり, 解探索ダイ ナミクスが分かっているニューロン選択法 C とニューロン 選択法 $\mathrm{A}$ 及び $\mathrm{B}$ を相互情報量を用いて比較する。これに より，もしあるニューロン選択法の相互情報量の特性が解 探索ダイナミクスが分かっているニューロン選択法 C と同 じであれば，その選択法を用いたシステムの解探索ダイナ ミクスも, ニューロン選択法 C と同等の解探索ダイナミク スであると結論づけることができると考えられる。

\section{2. 二次割当問題 $(\mathrm{QAP})$}

$\mathrm{QAP}$ はP 困難な組合せ最適化問題の 1 つである (5)。 問題サイズ $N$ の QAP は, $N \times N$ のつの行列, すなわ ち, $N$ 個の要素の内の 2 つの要素 $i$ と $j$ の距離から成る行 列 $\boldsymbol{A}$ と, 行列 $\boldsymbol{A}$ の要素とは独立な $N$ 個の要素間の相互関係 を表現する行列 $\boldsymbol{B} て ゙$ 定義される ${ }^{(5)}$ 。QAP の解は, 行列 $\boldsymbol{A}$ を定義する $N$ 個の要素に対応する $N$ 個のインデックスと, 行列 $\boldsymbol{B}$ を定義する $N$ 個の要素に対応する要素を持つ順列 $\boldsymbol{p}$ で表現できる ${ }^{(13)}($ 式 $(1))$ 。

$$
\begin{array}{rccl}
\text { index } & : & 1, \quad 2, \quad \cdots, \quad i, \quad \cdots, \quad N \\
\boldsymbol{p} & : & \{p(1), p(2), \cdots, p(i), \cdots, p(N)\}
\end{array}
$$

QAP のコスト関数 $F(\boldsymbol{p})$ は, 式 (1) の $\boldsymbol{p}$ に対して次式で 与えられる。

$$
F(\boldsymbol{p})=\sum_{i=1}^{N} \sum_{j=1}^{N} a_{i j} b_{p(i) p(j)}
$$

ここで, $a_{i j}$ は行列 $\boldsymbol{A}$ の $(i, j)$ 番目の要素, $b_{p(i) p(j)}$ は行列 $\boldsymbol{B}$ の $(p(i), p(j))$ 番目の要素を示す。 $\mathrm{QAP}$ はコスト関数 $F(\boldsymbol{p})$ が最小となる順列 $\boldsymbol{p}$ のインデックスと要素の組合せを求め る問題である。

\section{3. 同期更新指数減衰カオスタブーサーチ}

問題サイズ $N$ の場合， $N \times N$ 個のカオスニューロンか ら成るニューラルネットワークを用いる ${ }^{(3)}$ 。各ニューロン は下記に示す式 (3) から (5) のように，3つの内部状態を 持つ。よって，カオスニューラルネットワーク全体の次元 数は $3 N^{2}$ となる。次に, $2-\mathrm{opt}$ 交換アルゴリズムの動作の 例を Fig. 1 に示す。ネットワーク中の $(i, j)$ 番目のニュー

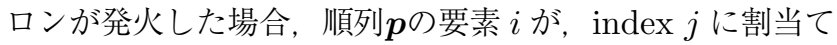
られる。これと同時に, 要素 $p(j)$ が index $q(i)$ に割当て られる。これらの要素の交換を, それぞれ, “ $(i, j)$ の割当 
index: $1 \quad \ldots \quad \ldots \quad j \quad \ldots \quad q(i) \ldots, \quad n$

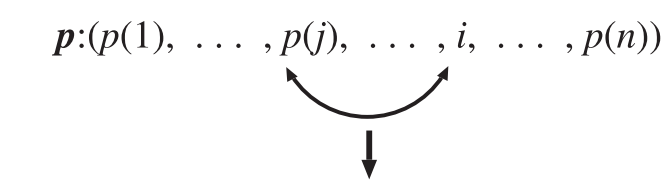

index: $1 \quad \ldots \quad j \quad \ldots \quad q(i) \ldots \quad n$

$$
\boldsymbol{p}:(p(1), \ldots, i, \ldots, p(j), \ldots, p(n))
$$

Fig. 1. The schematic of the 2-opt exchange of elements in the permutation $\boldsymbol{p}$. In the 2-opt exchange, the $(i, j)$-assignment and the $(p(j), q(i))$ assignment occurs when the $(i, j)$ th neuron fires.

て”および “ $(p(j), q(i))$ の割当て”と呼ぶ ${ }^{(3)}$ 。この様に, 2 つの要素を互いに交換することにより，より良い解を探索 するヒューリスティックアルゴリズムを2-opt 交換アルゴ リズムと呼ぶ(12)。

非同期更新方式では，ネットワーク中の $(1,1)$ 番目の二 ユーロンから $(N, N)$ 番目のニューロンを, 順次一つずつ 更新する ${ }^{(2)(3)}$ 。この非同期更新では，一つのニューロンを 更新している間は他のニューロンの状態更新ができないた め, アナログハードウェアシステムの利点である並列処理 に適していない。

そこで，同時に全てのニューロンを更新する同期更新方 式が提案された ${ }^{(10)}$ 。この同期更新方式では, 全てのニュー ロンを並列的に同時に更新することで，実行時間が QAP の問題サイズに依存しなくなるという利点がある。

同期更新指数減衰カオスタブーサーチで用いるカオス ニューラルネットワーク中の $(i, j)$ 番目のニューロンのダ イナミクスは次のように表される(9)。

$$
\begin{aligned}
\xi_{i j}(t+1) & =\beta\left(F_{1}(t)-F_{i j}(t)\right) \cdots \cdots \cdots \cdots \cdots \\
\eta_{i j}(t+1) & =k_{f} \eta_{i j}(t)-\alpha_{\eta} X_{p(j) q(i)}(t)+R \cdots \cdots \\
\zeta_{i j}(t+1) & =k_{r} \zeta_{i j}(t)-\alpha_{\zeta} x_{i j}(t)+R \cdots \cdots \cdots \cdots \\
y_{i j}(t+1) & =\xi_{i j}(t+1)+\eta_{i j}(t+1)+\zeta_{i j}(t+1) \cdots \cdots \\
x_{i j}(t+1) & =f\left(y_{i j}(t+1)\right) \cdots \cdots \cdots \cdots \cdots \cdots
\end{aligned}
$$

ここで, $\xi_{i j}(t+1)$ は離散時刻 $t+1$ におけるコストのゲイ ンに対応する内部状態項, $F_{1}(t)$ は現在のコスト, $F_{i j}(t)$ は $(i, j)$ 割当てを行った場合のコスト, $\beta$ はゲインのスケーリ ングパラメータ, $\eta_{i j}(t+1)$ は $(p(j), q(i))$ 割当てのタブー 効果に対応する内部状態項, $\zeta_{i j}(t+1)$ は $(i, j)$ 割当てによ るタブー効果に対応する内部状態項, $\alpha_{\eta}, \alpha_{\zeta}$ は夕ブー効果 のスケーリングパラメータ, $k_{r}, k_{f}$ は夕ブー効果の減衰パ ラメータ, $R$ は正の外部バイアス, $y_{i j}(t+1)$ は内部状態の 総和, $x_{i j}(t+1)$ はニューロンの出力であり, $X_{p(j) q(i)}(t)$ は $(p(j), q(i))$ 割当てが行われたときに“1”となり，それ以 外では “ 0 ” となる 2 值補助変数である。 $f(\cdot)$ はニューロン の単調増加で連続な非線形出力関数であり, 次のように表 される。

$$
f(x)=\frac{1}{1+\exp (-x / \epsilon)}
$$

ここで, $\epsilon$ は正の定数で，ハードウェアに実装された特性を 近似するため $\epsilon=0.03$ とした。なお，以下で述べるシミュ レーション実験では，アナログハードウェア中のダイナミ カルノイズによる影響を考慮するため, 式 (4) と式 (5)の 代わりに次式を用いる，

$$
\begin{gathered}
\eta_{i j}(t+1)=k_{f} \eta_{i j}(t)-\alpha_{\eta} X_{p(j) q(i)}(t)+R+\epsilon_{1} \\
\ldots \ldots \ldots \ldots \ldots \ldots \\
\zeta_{i j}(t+1)=k_{r} \zeta_{i j}(t)-\alpha_{\zeta} x_{i j}(t)+R+\epsilon_{2} \cdots(10
\end{gathered}
$$

ここで, $\epsilon_{1}$ と $\epsilon_{2}$ はダイナミカルノイズに対応するノイズ 項である。

\section{4. ニューロン選択法}

同期更新方式では，問題サイズ $N$ の場合， $N \times N$ 個の ニューロンの内部状態を同時に更新する。この際, 更新後の 内部状態值が 0 以上のとき，ニューロンは発火したと定義 する。この様に全てのニューロンを同時に更新すると，複数 個のニューロンが同時に発火する可能性がある。ニューラ ルネットワークを用いたタブーサーチでは, 発火したニュー ロンに対応する 2-opt 交換を実行するため, 複数の二ュー ロンが同時に発火した場合，2-opt 交換の候補を一意に決定 することができない。そこで，発火した複数個のニューロ ンの中から 2-opt 交換対象を一つだけ選択する方法として, 以下に示すニューロン選択法 A と B が提案された ${ }^{(9)}{ }^{(14)}$ 。 また, シミュレーション実験において比較対象として用い るニューロン選択法 C も以下に示す。

〈4・1〉 ニューロン選択法 $\mathbf{A}$ 本論文では, 文献 (9) で 提案された方法を「ニューロン選択法 $\mathrm{A} 」$ と呼ぶ。以下で 述べるようにこの手法は, 並列的に作成した複数の順列候 補の内，最小コストを与える順列を最終的に採用するとい う理解しやすい手法である。すなわち, ニューロン選択法 $\mathrm{A}$ を用いたシステムの解探索ダイナミクスでは, 主に局所 的な探索が行われていると考えられる。この方式をまとめ ると以下のようになる。

a) 同期更新により, 同時に全てのニューロンの内部状態 を更新する。

b) 発火したニューロンの中で, 内部状態 $y_{i j}(t+1)$ の值 が大きい順にニューロンに順位を付ける。

c) 順位 1 のニューロンを用いて, 現在の順列 $\boldsymbol{p}_{\text {current }}$ の 要素に対して, 仮の 2-opt 交換を行う。この結果, 得ら れた順列を $p 1$ とする。順列 $p 1$ に対するコスト $F(p 1)$ を求める。ただし, 仮の 2-opt 交換では, 実際のニュー ロンの内部状態等には一切影響を与えないとする。

d) 次に, 順位 2 のニューロンを用いて, 現在の順列 $\boldsymbol{p}_{\text {current }}$ の要素に対して, 仮の 2-opt 交換を行う。こ の順列を $p 2$ とし, 順列 $p 2$ に対するコスト $F(p 2)$ を 求める。

e) 以下同様に, 順位 $U(U$ はパラメータ) まで繰り返す。 f) b) から e) により, $\boldsymbol{p 1}, \boldsymbol{p 2}, \ldots, \boldsymbol{p U}$ のそれぞれに 対するコスト $F(\boldsymbol{p} \mathbf{1}), F(\boldsymbol{p} \mathbf{2}), \ldots, F(\boldsymbol{p} U)$ が得られ 
る。これらの中で最小のコストを与えるニューロンを

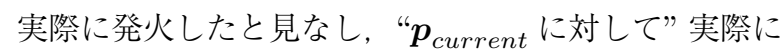
2-opt 交換を行う。この時, その他のニューロンは発 火したと見なさない。

$\langle\mathbf{4} \cdot 2\rangle$ ニューロン選択法 B 同期更新指数減衰力オ スタブーサーチの解探索能力をさらに向上させるため, 次 のようにニューロン選択法の改良が行われた ${ }^{(14)}$ 。これを本 論文では「ニューロン選択法 B」と呼ぶ。この方式は優れ た解法性能を有していることが示されているが(11)，アド ホックに作られた方法であり，作成した複数の順列候補の 内，最小コストを与える順列を採用するのではなく，その 順列の作成に用いた 2-opt 交換をそのまま元の順列に適用 する点が直感的には理解困難なアルゴリズムである。これ を以下に示す。

a), b), c) 手順 a) から c) はニューロン選択法 A と同じ。

d) 次に, 順位 2 のニューロンを用いて, “順列 $p 1$ の要 素に対し”仮の 2-opt 交換を行う。この順列を $\tilde{p} \mathbf{2}$ と し, 順列 $\tilde{\boldsymbol{p}} \mathbf{2}$ に対するコスト $F(\tilde{\boldsymbol{p}} \mathbf{2})$ を求める。

e) 以下同様に, 順位 $U$ まで繰り返す。

f) b) から e)により, $\boldsymbol{p} \mathbf{1}, \tilde{\boldsymbol{p}} \mathbf{2}, \ldots, \tilde{\boldsymbol{p}} \boldsymbol{U}$ のそれぞれに対 するコスト $F(\boldsymbol{p} \mathbf{1}), F(\tilde{\boldsymbol{p}} \mathbf{2}), \ldots, F(\tilde{\boldsymbol{p}} \boldsymbol{U})$ が得られる。 これらの内最小のコストを与えるニューロンのみを発 火したと見なし, “ $p_{\text {current }}$ に対して”実際に2-opt 交 換を行う。

〈4·3〉 ニューロン選択法 C 本論文では, ニューロ ン選択法のダイナミクスを検討するに当たり，比較対象と して以下に示す「ニューロン選択法 $\mathrm{C} 」 を$ をいる。

a), b), c), d), e) 手順 a) から e) はニューロン選択 法 B と同じ。

f) b) から e)により, $\boldsymbol{p} \mathbf{1}, \tilde{\boldsymbol{p}} \mathbf{2}, \ldots, \tilde{\boldsymbol{p} U} \boldsymbol{U}$ のそれぞれに対 するコスト $F(\boldsymbol{p} \mathbf{1}), F(\tilde{\boldsymbol{p}} \mathbf{2}), \ldots, F(\tilde{\boldsymbol{p}} \boldsymbol{U})$ が得られる。 これらの内最小コストを与える順列 $\tilde{\boldsymbol{p}} \boldsymbol{i}(1 \leq i \leq N)$ を 更新後の順列として扱う。すなわち $\boldsymbol{p}_{\text {current }}$ を $\tilde{\boldsymbol{p}} \boldsymbol{i}$ で 置き換える。

ニューロン選択法 A と B では，交換後の順列は，現在の順 列 $\boldsymbol{p}_{\text {current }}$ に対して，実際の 2-opt 交換を一度だけ行った 順列となる。それに対し，ニューロン選択法 C では，最小コ ストを与える順列 $\tilde{\boldsymbol{p}} \boldsymbol{i}$ を更新後の順列とするため, $\boldsymbol{p}_{\text {current }}$ から 2-opt 交換を $i$ 回行った順列となる。よって, $i$ が大き いほど, $\boldsymbol{p}_{\text {current }}$ とは大きく異なった順列となる可能性があ り，解空間を広く探索すると考えられる。このため，ニュー ロン選択法 $\mathrm{C}$ を比較対象とした。

\section{5. カオスニューラルネットワークにおける相互情 報量}

前章で述べたニューロン選択法 $\mathrm{A}$ から $\mathrm{C}$ を用いた指数 減衰カオスタブーサーチの解探索ダイナミクスを評価する ため, 本章で述べる空間相互情報量と時間相互情報量の 2 種類の相互情報量を用いる。解析対象とするカオスニュー ラルネットワークは，1章で述べたように高次元である上，
ニューロン選択法や $2-o p t$ 法による外部入力の影響が大き い。そのため, 通常低次元のカオスカ学系で用いられるリ アプノフスペクトル解析や次元解析などの評価手法を適用 する事が困難である。また，ハードウェアシステムを前提と しているため, 高精度で多チャネルのアナログ值を必要と する手法も適していない。これに対し，相互情報量の計算 には二值化されたニューロンの出力のみを用いるため, 比 較的高次元の系や実験系のダイナミクスを評価するのに適 していると考えられる。また，ニューロン選択法による時 空間的な発火ダイナミクスと, カオスタブーサーチによる 解の探索ダイナミクスには密接な関係がある。一方, 空間 相互情報量と時間相互情報量にはニューロンの時空間的な 発火情報が含まれているので，これらの相互情報量はシス テムの解探索ダイナミクスの 1 つの尺度として適している と考えられる。

相互情報量は, ある 2 つの事象 $\mathrm{P}, \mathrm{Q}$ において, 一方を知 ることにより他方についてどれくらい情報が得られるかを表 す量である。相互情報量が大きな值であれば $\mathrm{P}$ あるいは $\mathrm{Q}$ から受けた情報が多いことを示し，小さければその逆を示す。

$\langle\mathbf{5} \cdot \mathbf{1}\rangle$ 空間相互情報量の算出方法 空間相互情報量は 自身の状態変化に関する相互情報量だけでなく, 他のニュー ロン間の相互情報量を考慮したネットワーク全体の相互情 報量である。平均空間相互情報量は以下に与えられる。

$$
\begin{aligned}
M I_{s p}= & \frac{1}{N^{2}} \sum_{i=1}^{N} \sum_{j=1}^{N} M I_{i j} \ldots \ldots \ldots \ldots \ldots \ldots \\
M I_{i j}= & H\left(x_{i}\left(t_{n}\right)\right)-H\left(x_{i}\left(t_{n}\right) \backslash x_{j}\left(t_{n-1}\right)\right) \cdots \\
= & \sum_{k=1}^{2} \sum_{l=1}^{2} P\left(x_{i}\left(t_{n}\right)_{k}, x_{j}\left(t_{n-1}\right)_{l}\right) \\
& \times \log _{2} \frac{P\left(x_{i}\left(t_{n}\right)_{k}, x_{j}\left(t_{n-1}\right)_{l}\right)}{P\left(x_{i}\left(t_{n}\right)_{k}\right) P\left(x_{j}\left(t_{n-1}\right)_{l}\right)} \ldots .
\end{aligned}
$$

ここで, $M I_{s p}$ は全ニューロンの平均空間相互情報量, $N$ は ニューロン数, $M I_{i j}$ は $j$ 番目のニューロンから得られる $i$ 番 目のニューロンについての空間相互情報量, $H\left(x_{i}\left(t_{n}\right)\right)$ は時 刻 $t_{n}$ でのエントロピー, $H\left(x_{i}\left(t_{n}\right) \backslash x_{j}\left(t_{n-1}\right)\right)$ は条件付エン トロピー, $P\left(x_{i}\left(t_{n}\right)_{k}\right)$ は $t_{n}$ のときの $i$ 番目のニューロンの $k$ 番目の事象の生起確率 (ここではニューロンの発火か非発火 の 2 つの事象を扱うため $k=1,2), P\left(x_{i}\left(t_{n}\right)_{k}, x_{j}\left(t_{n-1}\right)_{l}\right)$ は同時生起確率である。

$\langle\mathbf{5} \cdot \mathbf{2}\rangle \quad$ 時間相互情報量の算出方法 時間相互情報量 は自身の過去と現在の状態に対する相互情報量である。平 均時間相互情報量を以下に示す ${ }^{(15)}$ 。

$$
\begin{aligned}
M I_{t m p} & =\frac{1}{N} \sum_{i=1}^{N} M I_{i} \ldots \ldots \ldots \ldots \ldots \ldots \\
M I_{i}= & H\left(x_{i}\left(t_{n}\right)\right)-H\left(x_{i}\left(t_{n}\right) \backslash x_{i}\left(t_{n-1}\right)\right) \cdots \\
= & \sum_{k=1}^{2} \sum_{l=1}^{2} P\left(x_{i}\left(t_{n}\right)_{k}, x_{i}\left(t_{n-1}\right)_{l}\right) \\
& \times \log _{2} \frac{P\left(x_{i}\left(t_{n}\right)_{k}, x_{i}\left(t_{n-1}\right)_{l}\right)}{P\left(x_{i}\left(t_{n}\right)_{k}\right) P\left(x_{i}\left(t_{n-1}\right)_{l}\right)} \cdots \cdots
\end{aligned}
$$


ここで, $M I_{t m p}$ は全ニューロンの平均時間相互情報量, $M I_{i}$ はニューロン $i$ における時間相互情報量である。

\section{6. シミュレーション実験}

数值シミュレーションで複数の QAP を解き，優れた解の 探索が行われるときにどのようなダイナミクスが寄与して いるかを評価する。以下では, 解の探索能力とネットワー クダイナミクスの関係を 5 章で述べた 2 つの相互情報量を 用いて検討する。

数值シミュレーションでは QAP Library ${ }^{(5)}$ のベンチマー ク問題として, Rou20, Tai20a, Had20, Lipa20b, Tho30, Nug30 問題について行い, 全ての問題で同等の相互情報量特 性を確認した。本論文では，誌面の都合上，典型的な例とし てHad20, Lipa20b, Nug30 問題のシミュレーション結果を 示す。Lipa20b 問題は特定のパラメータで必ず最適解に到達 することが確認されている問題, $\operatorname{Had} 20$ 問題はニューロン選 択法による解法性能の差が小さい問題, Nug30 問題は解法性 能の差が大きい問題である。カオスニューラルネットワーク のパラメータは $\alpha_{\zeta}=1.0$ および $R=0.1$ と固定し, $\alpha_{\eta}, \beta$, $k_{r}, k_{f}$ は $\{0.1,0.3,0.4,0.5,0.65,0.7,0.75,0.9,0.95,1.0\}$ の中からそれぞれ選択した。さらに, 各問題間で共通のネッ トワークパラメータを用いて比較を行うため, 各問題に対 して良好な最適解到達率と平均誤差率を与えるパラメータ を 20 通り選び出し，これらをパラメータセットとし，以下 のシミュレーションで用いた。ここで, 最適解到達率 $A R$ は次のように定義される。

$$
A R=\frac{O N}{100} \times 100
$$

ここで, $O N$ は最適解が得られたトライアル数である。な お，シミュレーション実験ではネットワークの初期值をラ ンダムな発火パターンとして 100 トライアルずつ実施した。 さらに平均誤差率 $A G$ は,

$$
A G=\frac{\sum_{n=1}^{100} E M_{n}}{100} \times 100
$$

とする。ここで, $E M_{n}$ は $n$ 番目のトライアルで得られた 最良解と最適解との誤差である。

また，各パラメータセットにおいて，ニューロン選択数を $U=\{1,2,3,4,5\}$ と変化させた。ただし, $U=1$ の場合は, 常に内部状態值が最も大きいニューロンを選択するため, 文 献(9) と等価な手法となる。さらに, 式 (9) および (10) 中の $\epsilon_{1}$ と $\epsilon_{2}$ は，それぞれ独立で振幅が \pm 0.04 の一様乱数を用 いる。また，各パラメータセットに打いて，1トライアルを 10,000 イタレーションとする。ここで1イタレーションとは, 同期更新を行い実際の交換を 1 回行う事と定義する。

初めに, 各ニューロン選択法の解法性能の評価を行う。カ オスニューラルネットワークのパラメータは Table 1 を用 い, ニューロン選択数を $U=5$ とした。各ニューロン選択 法の最適解到達率 $A R$ と平均誤差率 $A G$ を Table 2 と 3 に それぞれ示す。なお，表中で $U=1$ は常に内部状態值が最も
Table 1. Values of the network parameters used in the simulations with the chaotic neural network.

\begin{tabular}{ccccc}
\hline Instance & $\alpha_{\eta}$ & $\beta$ & $k_{r}$ & $k_{f}$ \\
\hline Had20 & 0.1 & 0.7 & 0.7 & 0.7 \\
Lipa20b & 0.1 & 0.3 & 0.9 & 0.9 \\
Nug30 & 0.1 & 0.7 & 0.7 & 0.7 \\
\hline
\end{tabular}

Table 2. Arrival rate for the optimal solution $A R$.

\begin{tabular}{ccccc}
\hline Instance & U=1 & Method A & Method B & Method C \\
\hline Had20 & 9 & 41 & 50 & 50 \\
Lipa20b & 100 & 100 & 100 & 100 \\
Nug30 & 14 & 0 & 53 & 56 \\
\hline
\end{tabular}

Table 3. Average gap from the optimum solution $A G$.

\begin{tabular}{ccccc}
\hline Instance & $\mathrm{U}=1$ & Method A & Method B & Method C \\
\hline Had20 & 0.326 & 0.222 & 0.189 & 0.194 \\
Lipa20b & 0.000 & 0.000 & 0.000 & 0.000 \\
Nug30 & 0.248 & 1.174 & 0.119 & 0.114 \\
\hline
\end{tabular}

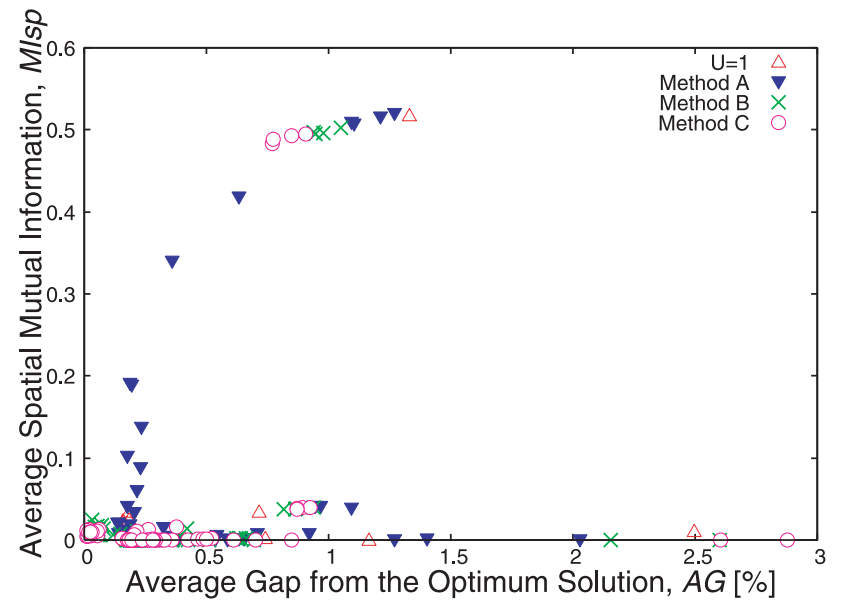

Fig. 2. Average spatial mutual information $M I_{s p}$ vs. average gap from the optimum solution $A G$ for $\operatorname{Had} 20$.

大きいニューロンを選択する手法, Method A はニューロ ン選択法 A, Method B はニューロン選択法 B, Method $\mathrm{C}$ はニューロン選択法 $\mathrm{C}$ を示す。Table 2 と 3 の結果より, ニューロン選択法 $\mathrm{B}$ と C は常に内部状態值が最も大きい ニューロンを選択する手法やニューロン選択法 A よりも優 れた解法性能を持つことが分かる。

次に, 各ニューロン選択法に対する平均空間相互情報量 と式 (18) より求めた平均誤差率 $A G$ との関係を $\operatorname{Had} 20$, Lipa20b 拉よび Nug30 について，それぞれ Fig. 2 から 4 に示す。Fig. 2 から 4 に示す結果より, 良好な結果を示す パラメータセットに対しては, 平均空間相互情報量は全体 的に低いことが分かる。また, Fig. 4 より, 特にニューロ ン選択法 A に関して明らかなように, 平均誤差率が悪い場 合, 平均空間相互情報量が高い值までばらつくことが分か る。これに対し, ニューロン選択法 $\mathrm{B}$ と C に関しては, 平 均空間相互情報量の分布には差は見られず，さらにニュー ロン選択法 A の分布とは異なる。

次に, 各ニューロン選択法に対する平均時間相互情報量と 


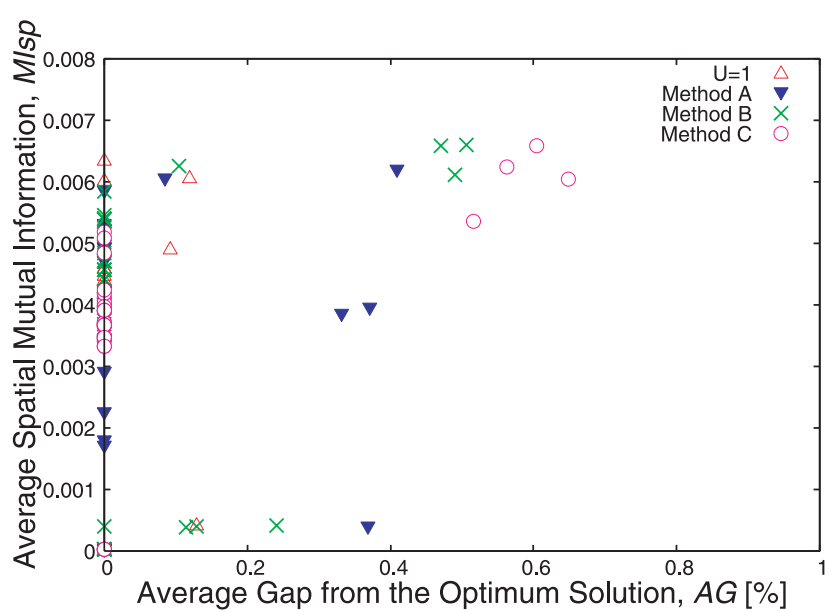

Fig. 3. Average spatial mutual information $M I_{s p}$ vs. average gap from the optimum solution $A G$ for Lipa20b.

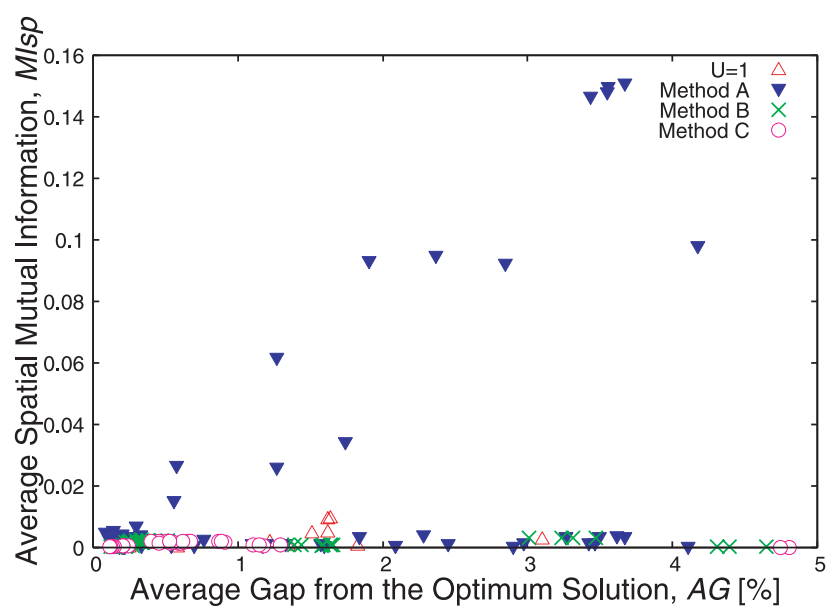

Fig. 4. Average spatial mutual information $M I_{s p}$ vs. average gap from the optimum solution $A G$ for Nug30.

平均誤差率 $A G$ との関係を $\mathrm{Had} 20, \mathrm{Lipa} 20 \mathrm{~b}, \mathrm{Nug} 30$ に対 して，それぞれFig. 5 から 7 に示す。Fig. 5 から 7 より, 最 適解が得られた時 $(A G=0)$ には, 平均時間相互情報量はあ る特定の值を示していることが分かる。このことから，性能 が良い時は平均時間相互情報量は問題に依存した特定の值に なると考えられる。例えば, Fig. 6 において，AG=0に対 して，平均時間相互情報量が $0.01 ， 0.04$ や 0.08 付近に集中 している。ところで, Fig. 5 から 7 より, 平均空間相互情報 量と同様に, ニューロン選択法 B と C の平均時間相互情報量 は同じ傾向である。一方, ニューロン選択法 $\mathrm{A}$ に関してはこ れらと異なり，Fig. 7 に示すように，平均誤差率が悪い場合 は平均時間相互情報量が高い值までばらつくことが分かる。

以上をまとめると, ニューロン選択法 A は, 解法性能が ニューロン選択法 B や C よりも悪く, 平均空間相互情報量 と平均時間相互情報量は共に高い值までばらつく。これに 対し, ニューロン選択法 B と C は, 良い特性の場合には平 均空間相互情報量は全体的に低く, さらに, 平均時間相互 情報量が問題に依存した特定の值を示す。これらから，相

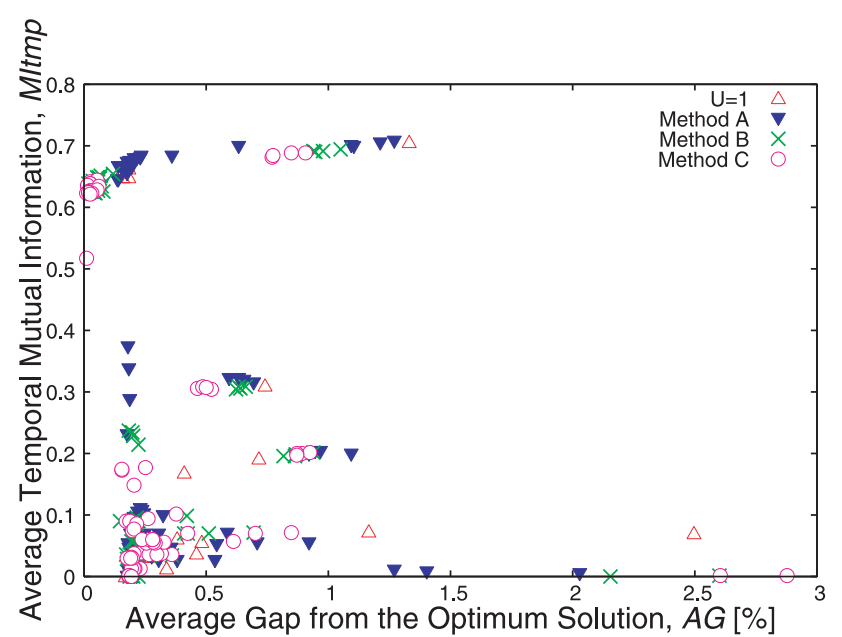

Fig. 5. Average temporal mutual information $M I_{t m p}$ vs. average gap from the optimum solution $A G$ for Had20.

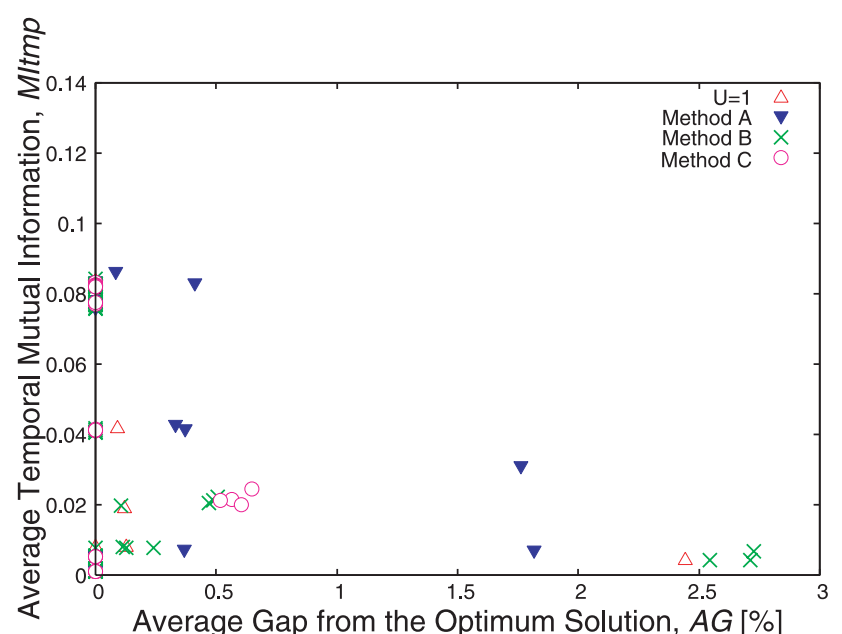

Fig. 6. Average temporal mutual information $M I_{t m p}$ vs. average gap from the optimum solution $A G$ for Lipa20b.

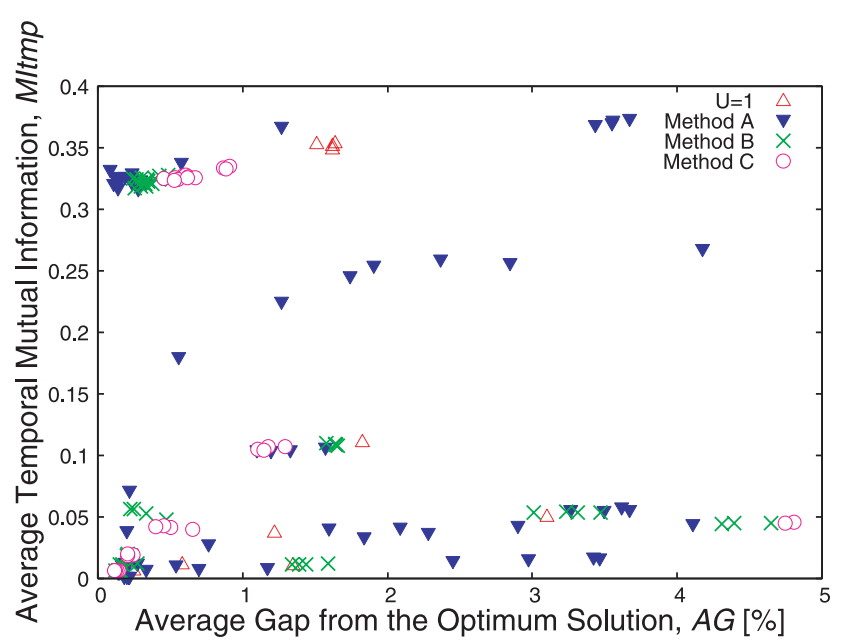

Fig. 7. Average temporal mutual information $M I_{t m p}$ vs. average gap from the optimum solution $A G$ for Nug30. 
互情報量を尺度とした場合，ニューロン選択法 B の解探索 ダイナミクスはニューロン選択法 $\mathrm{C}$ のそれと同等であり, 主に局所的な探索を繰り返すニューロン選択法 A のダイナ ミクスとは異なることが分かる。すなわち, ニューロン選 択法 B を用いたシステムの解探索ダイナミクスは, ニュー ロン選択法 $\mathrm{C}$ を用いたシステムと同様に，解空間を広くか つ局所的には深く探索するダイナミクスであると推測され る。すなわち, この様な解探索ダイナミクスによりニュー ロン選択法 B が高い解法性能を得ていると考えられる。

\section{7. まとめ}

ニューロン選択法を用いた同期更新指数減衰カオスタブー サーチの解探索ダイナミクスを評価するため，平均空間相 互情報量および平均時間相互情報量を用いた解析を行った。 この際, 解探索ダイナミクスが明らかなニューロン選択法 C を比較対象とし, 相互情報量を 1 つの尺度として用いる ことで，ニューロン選択法 $\mathrm{A}$ および $\mathrm{B}$ の解探索ダイナミ クスを評価した。その結果, 解法性能が悪いニューロン選 択法 A では平均空間相互情報量と平均時間相互情報量は 共に高い值までばらつき，性能が高いニューロン選択法 B と C の平均空間相互情報量は全体的に低い值を示した。ま た，二ューロン選択法 B と C の平均時間相互情報量は特 定の值に集中する傾向が見られた。これらの結果から，平 均空間相互情報量と平均時間相互情報量が共に比較的低く, 平均時間相互情報量が問題に依存したある特定の值に近い 場合に良い結果が得られることが定性的に分かった。また， ニューロン選択法 $\mathrm{B}$ と $\mathrm{C}$ の平均空間相互情報量と平均時 間相互情報量は共に同じ傾向を示し，ニューロン選択法 $\mathrm{A}$ とは異なる傾向を示した。このことから, ニューロン選択 法 B と C の解探索ダイナミクスは, 主に局所的な探索を 繰り返すニューロン選択法 $\mathrm{A}$ の解探索ダイナミクスとは異 なることが分かった。従って，これまで解探索ダイナミク スが不明であったニューロン選択法 B は, ニューロン選択 法 C と同様に，解空間を広くかつ局所的に深く探索するダ イナミクスを持つと考えられる。

今後は, 相互情報量による解析を他の最適化手法にも適 用して比較をし, 得られた特徵を活かした有効なカオス夕 ブーサーチの実現法を検討する。また，より明確な解析を するため, サロゲート法による検証や相互情報量と他の評 価指標の併用なども検討する。

\section{謝 辞}

本研究の一部は, 日本学術振興会の最先端研究開発支援 プログラム，及び，科研費基盤研究 $(B)(203000085)$ の援 助により行なわれた。

(平成 22 年 7 月 23 日受付, 平成 22 年 11 月 20 日再受付)

\section{文献}

(1) E. Taillard: "Robust tabu search for the quadratic assignment problems", Parallel Computing, Vol.17, pp.443-455
(1991)

(2) M. Hasegawa, T. Ikeguchi, and K. Aihara: "A novel chaotic search for quadratic assignment problems", European Journal of Operational Research, Vol.139, pp.543-556 (2002-6)

(3) M. Hasegawa, T. Ikeguchi, and K. Aihara: "Exponential and chaotic neurodynaminal tabu searches for quadratic assignment problems", Control and Cybernetics, Vol.29, No.3, pp.773-788 (2000-9)

(4) M. Hasegawa, T. Ikeguchi, and K. Aihara: "Solving large scale traveling salesman problems by chaotic neurodynamics", Neural Networks, Vol.15, pp.271-283 (2002)

(5) R. E. Burkard, S. E. Karisch, and F. Rendl: "QAPLIB A quadratic assignment problem library", http://www.opt. math.tu-graz.ac.at/qaplib/

(6) Y. Horio and K. Aihara: "Analog computation through highdimensional physical chaotic neuro-dynamics", Physica D: Nonlinear Phenomena, Vol.237, pp.1215-1225 (2008-7)

(7) Y. Horio, K. Aihara, and O. Yamamoto: "Neuron-synapse IC chip-set for large-scale chaotic neural networks", IEEE Trans. Neural Networks, Vol.14, No.5, pp.1393-1403 (20039)

(8) K. Tanaka, Y. Horio, and K. Aihara: "A modified algorithm for the quadratic assignment problem using chaotic-neurodynamics for VLSI implementation", in Proc. Int. Joint Conf. on Neural Networks, pp.240-245 (2001-7)

(9) N. Yokota, Y. Horio, and K. Aihara: "A synchronous exponential chaotic tabu search for quadratic assignment problems", in Proc. Int. Workshop on Nonlinear Circuit and Signal Processing, CD-ROM (2008-3)

(10) N. Yokota, Y. Horio, and K. Aihara: "A modified synchronous exponential chaotic tabu search for quadratic assignment problems", IEICE Technical Report, Vol.NLP107, No.561, pp.49-54 (2008-3) (in japanese)

横田直人・堀尾喜彦·合原一幸:「二次割り当て問題のための同期更 新指数隇衰カオスタブーサーチの改良」, 信学技報, Vol.NLP107, No.561, pp.49-54 (2008-3)

(11) T. Kawamura and Y. Horio: "Evaluation of neuron selection techniques for synchronous exponential chaotic tabu search for quadratic assignment problems", IEICE Technical Report, Vol.NLP109, No.269, pp.67-71 (2009-11) (in japanese) 河村鉄夫 · 堀尾喜彦: 「二次割当問題のための同期更新指数隇衰力オ スタブーサーチに用いるニューロン選択法の性能評価」，信学技報, Vol.NLP109, No.269, pp.67-71 (2009-11)

(12) S. Lin: "Computer solutions of the traveling salesman problem", Bell System Tech. J. 44, pp.2245-2269 (1965)

(13) F. Hillier and M. Michael: "Quadratic assignment problem algorithms and the location of indivisible facilities", Management Science, Vol.13, No.1, Series A, Sciences, pp.42-57 (1966-9)

(14) A. Shirakuma, Y. Horio, and K. Aihara: "An improved neuron selection technique in an exponential chaotic tabu search hardware system for large-scale quadratic assignment problems", in Proc. Int. Workshop on Nonlinear Circuit and Signal Processing, CD-ROM (2009-3)

(15) O. Masanao and K. Yuba: "Associative memory and amount of mutual information in a chaotic neural network introducing function typed synaptic weights", in Proc. of the 9th International Comference on Neural Information Processing ICONIP'02, Vol.4, pp.1617-1622 (2002-11)

河 村 鉄 夫（非会員） 1985 年生。 2009 年 3 月東京理科大

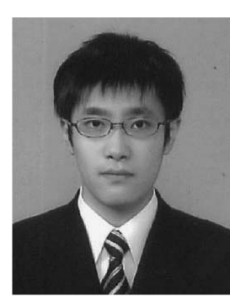
学工学部第一部電気工学科卒業。2009 年 4 月東 京電機大学大学院工学研究科電気電子工学専攻入 学。現在, 修士課程に在籍。組合せ最適化問題, 複雑系コンピューティングの研究に従事。 
堀 尾 喜 彦 (非会員) 1982 年慶應義塾大学工学部電気工学 科卒業。1987 年同大大学院博士課程修了。同年 東京電機大学工学部助手。2000 年同教授。1992 年〜1994 年 米国コロンビア大学客員教授。工学 博士。非線形集積回路, 複雑系コンピューティン グの研究に従事。
長谷川 幹 雄 (非会員) 1995 年東京理科大学基礎工学部電子応

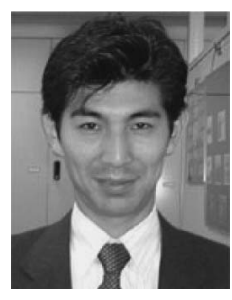
用工学科卒。 2000 年同大学院博士課程了。 1997 年より 2000 年まで日本学術振興会特別研究員 (DC1)。2000 年郵政省通信総合研究所（現在： 独立行政法人情報通信研究機構) 入所。 2007 年 東京理科大学工学部第一部電気工学科講師。2010 年同准教授。博士 (工学)。カオス, ニューラル ネットワーク，組合せ最適化，ユビキタスモバイ ルネットワーク,コグニティブ無線ネットワークに関する研究に従事。 IEEE，電子情報通信学会各会員。 